\title{
Intermédialités
}

Histoire et théorie des arts, des lettres et des techniques

Intermediality

History and Theory of the Arts, Literature and Technologies

\section{“A Bridge Between Imagination and Reality Must Be Built": Film and Spatial Critique in the Work of Patrick Keiller}

\section{Anthony Kinik}

Numéro 14, automne 2009

bâtir

build

URI : https://id.erudit.org/iderudit/044412ar

DOI : https://doi.org/10.7202/044412ar

Aller au sommaire du numéro

Éditeur(s)

Revue Intermédialités (Presses de l’Université de Montréal)

ISSN

1705-8546 (imprimé)

1920-3136 (numérique)

Découvrir la revue

Citer cet article

Kinik, A. (2009). “A Bridge Between Imagination and Reality Must Be Built”: Film and Spatial Critique in the Work of Patrick Keiller. Intermédialités /

Intermediality, (14), 105-125. https://doi.org/10.7202/044412ar
Résumé de l'article

Cet article s'inscrit dans la continuité d'études portant sur l'oeuvre de Patrick Keiller, en prenant en considération sa carrière d'écrivain et de chercheur en marge de sa pratique cinématographique, et, plus particulièrement, ses écrits sur le cinéma, l'histoire de l'art et la géographie. Cette perspective permet de souligner la contribution de Keiller à une tradition esthétique et critique préoccupée par la question de l'environnement bâti, dont l'émergence remonte à la fin du $19^{\mathrm{e}}$ siècle - avec des implications directes pour le cinéma. En fin de parcours, l'auteur propose une analyse détaillée de Robinson in Space (1997) afin d'expliciter l'utilisation par Keiller du dispositif filmique comme forme de médiation critique de l'espace. 


\title{
"A Bridge Between Imagination and Reality Must Be Built": Film and Spatial Critique in the Work of Patrick Keiller
}

\author{
AnthONY Kinik
}

\section{SHATTERED SPACE, DYNAMITE}

If Patrick Keiller's two most celebrated films, London (1994) and Robinson in Space (1997), are notable examples of a movement among British filmmakers of the 1980 s and 1990 s to respond to the turmoil, division, and crises that were so much a part of the Thatcher and Major years, they are among the most unusual of this diverse and oftentimes strikingly original group of films. While other filmmakers of the period employed decidedly allegorical anti-realist narratives and non-narrative collages (such as those of Greenaway and Jarman) or narratives that worked with the social realist tradition (such as those of Terence Davies, Mike Leigh, and Ken Loach), Keiller used a rather different approach, one that experimented with documentary form in ways that remain striking and remarkably daring. So, for instance, Keiller dedicated the first of these films to a study of "the problem of London" and the second to a study of "the problem of England," but he did so through the use of two fictional interlocutors - "Robinson" and "The Narrator" - neither of whom is actually ever depicted on screen. ${ }^{1}$ These narrative elements are then embedded in films that are firmly rooted in the documentary

1. In fact, the only trace of either of these two characters is the voice of the inimitable Paul Scofield as "The Narrator," an incongruity about which Iain Sinclair has noted: "[It] is so clear that he is not the narrator. It's a performance - tired, slightly camp, detached." Iain Sinclair, "Necropolis of Fretful Ghosts", Sight and Sound 4, June 1994, p. 12-15 (here p. 13). 
mode through Keiller's minimalist camerawork, which is primarily made up of carefully composed, largely static shots of England's landscapes and townscapes, shots whose stillness and duration masks Keiller's "fanatical attention... [to] people, traffic, clouds, leaves, the flow of water - anything that moved."

In many ways, Keiller's Robinson films built upon a cinematic aesthetic Keiller had developed in the 1980s, after he moved from a career in architecture to one in filmmaking, joined the London Film-makers' Co-op (LFMC), and began to make the series of offbeat and intriguing short films that established Keiller's reputation as a rising filmmaker. These films included Stonebridge Park (1981), Norwood (1983), The End (1986), Valtos, or The Veil (1987), and they were characterized by an economical and hybrid approach to filmmaking - one that combined elements of narrative, documentary, and experimental modes of address with a fascination for the built environment ${ }^{3}$ - and a self-consciously continental sensibility, all of which anticipated key aspects of his Robinson films and indicated an indebtedness to the tradition of modernist city films that began in the early 1920s. These films also initiated a number of other recurring patterns in Keiller's work: an interest in travel stories and the travelogue as a narrative form, an interest in intertextuality (within his work as well as without), an interest in making sequels, and an attraction to dry, mordant, at times absurdist humour. ${ }^{4}$

But just as importantly, the 1980s was also the period when Keiller began to assert himself as a scholar, writing essays on the topic of film, art history, and geography (cinematic, painterly, photographic, socio-economic, and otherwise), most notably in the pages of Undercut, where he published two essays that would prove to be of lasting significance: "The Poetic Experience of Townscape and

2. Larry Sider, "Looking for the Wind", in Ilona Halberstadt, Pix 2, London, BFI, 1997, p. 168-170 (here, p. 169).

3. The first two films in particular focus on two of London's least iconic neighborhoods: Stonebridge Park and Norwood.

4. This combination of cinematic hybridity and mordant humour was not uncommon at the LFMC at the time. See John Smith's The Black Tower (1987), for instance, a film about whose method its director once said, "If you look hard enough, all meanings can be found or produced close to home." John Smith talking with Cate Elwes, John Smith: Film and Video Works 1971-2002, Bristol, Picture this Moving Image and Watershed Media Center, 2002, p. 70. (Also available at http//archive.senserofcinema.com/contents/o3/29/ John_Smith.html, last access July 13, 2010) This philosophy would become of vital importance to Keiller's Robinson films. 
Landscape, and Some Ways of Depicting It"5 and "Atmosphere, Palimpsest and Other Interpretations of Landscape." Of these, the former is particularly pertinent for it captures a group of fixations that had been at the forefront of Keiller's thoughts and crucial to his practice for some time, but that remained repressed for a decade after he got involved in filmmaking. Ten years later, in 2002, Keiller still described this pre-cinematic project as a kind of photographic survey of "found" architecture and urban readymades in London, one that drew inspiration from the photography of Bernd and Hilla Becher as well as from the urban reportage of the Surrealists (especially Louis Aragon) and Walter Benjamin, one that he hoped to refine to the point that it would become possible "to transform even the most familiar spaces of the city centre-Piccadilly Circus, say, or Regent Street." Keiller "recovered the idea, almost inadvertently," when he began making London, "by which time the process of defamiliarisation had become second nature," 7 but there it was fully expressed in the pages of Undercut ("The desire to transform the world is not uncommon, and there are a number of ways of fulfilling it..."), alongside his analysis of a constellation of $19^{\text {th }}$ and early $20^{\text {th }}$ century artists whose work had been pivotal in the development of this brand of modernism: Poe, Baudelaire, Apollinaire, Breton, Aragon, Lotar, Atget, and so on. ${ }^{8}$

Keiller's unorthodox approach to documentary representation in his two Robinson films has quite justly received a fair bit of attention (and it will again in this very essay), but what's often overlooked in discussions of Keiller's film work is his rather prolific output as a critic, historian, theoretician, and essayist, work that in some regards has taken precedence in the years since he became a Research Fellow with the Royal College of Art, London. In other words, what's often overlooked are not only Keiller's own extra-filmic contributions to the fields of film studies, art history, and urban studies, but his contributions to the understanding of his very own work. This comprehensive account provides deeper

5. Patrick Keiller, "The Poetic Experience of Townscape and Landscape, and Some Ways of Depicting It" [1981-1982], in Nina Danino, and Michael Mazière (eds.), The Undercut Reader: Critical Writings on Artists' Film and Video, London and New York, Wallflower Press, 2003, p. 75-83.

6. Patrick Keiller, "Atmosphere, Palimpsest and Other Interpretations of Landscape" [1983], in Danino and Mazière (eds.), 2003, p. 204-208.

7. Patrick Keiller, "Architectural Cinematography," in Kester Rattenbury (ed.), This is not Architecture: Media Constructions, London and New York, Routledge, 2002, p. 37-44 (here, p. 38-39).

8. Keiller, 2003, p. 75. 
insight into the method behind Keiller's probing inquiries about the nature of socio-economic space, but it also underlines his participation in a tradition of theoretical, historical, and practical engagements with the built environment, one with tremendous implications for cinema.

Thus, in 2004, Keiller published an article entitled "Tram Rides and Other Virtual Landscapes" in Toulmin, The Lost World of Mitchell and Kenyon, an anthology ( edited by Toulmin, Popple and Russell) dedicated to a recently rediscovered treasure trove of early British films from the first few years of the $20^{\text {th }}$ century now known as the Mitchell \& Kenyon films, after the Blackburnbased company that produced them. ${ }^{9}$ Most of the article concerns Keiller's interest in the collection's tram films - actualités with self-explanatory titles such as Tram Journey into Halifax (1902) - and the experience he had when he revisited the locations documented by these films in Nottingham and Halifax a century later. ${ }^{10}$ This simple experiment in time travel from the early zooos into the virtual landscapes of the early 1900 allows Keiller to see just how the built environment of these cities has changed over the course of a century. His conclusion, motivated by a project he was working on at the time entitled The City of the Future, a project that became a multi-screen, multimedia installation and "virtual landscape" of the same name, ${ }^{11}$ is presented rather modestly:

The spaces of the films were dynamic, subject to tensions as unsettling as (and sometimes surprisingly similar to) those we experience today. Cities are increasingly seen as processes structured in time. In these remarkable films, we can explore some of the spaces of the past, in order to better anticipate the spaces of the future. ${ }^{12}$

The essay's introduction, on the other hand, is something altogether different. Here, Keiller begins by writing about how "the spaces and spatial experiences characteristic of industrialized economies underwent significant transformation" between the opening decade of the $20^{\text {th }}$ century and the outbreak of World War I, and he includes a passage from the work of Henri Lefebvre to illustrate his point:

9. Patrick Keiller, "Tram Rides and Other Virtual Landscapes" in Vanessa Toulmin, Simon Popple and Patrick Russell (eds.), The Lost World of Mitchell \& Kenyon: Edwardian Britain on Film, London, BFI, 2004, p. 191-200

10. Ibid., p. 193 .

11. The City of the Future was displayed most recently at the British Film Institute's Southbank gallery between November 2007 and February 2008.

12. Keiller, 2004, p. 199. 
“A BRIDGE BETWEEN IMAGinAtion AND REALity MUST BE BUiLt”

The fact is that around 1910 a certain space was shattered. It was the space of common sense, of knowledge (savoir), of social practice, of political power, a space hitherto enshrined in everyday discourse, just as in abstract thought, as the environment of and channel for communications; the space, too, of classical perspective and geometry, developed from the Renaissance onwards on the basis of the Greek tradition (Euclid, logic) and bodied forth in Western art and philosophy, as in the form of the city and the town... Euclidean and perspectivist space have disappeared as the systems of reference, along with other 'commonplaces' such as the town, history, paternity, the tonal system in music, traditional morality, and so forth. This was truly a crucial moment. ${ }^{13}$

Keiller then continues by describing a number of theorists and writers - Stephen Kern, John Berger, and Reyner Banham among them - who've also pointed to this very same period as being pivotal in the "evolution of modernist thinking." ${ }^{4}$ Thus, as Berger put it in his 1967 essay "The Moment of Cubism," this was a period defined by:

an interlocking world system of imperialism; opposed to it, a socialist international; the founding of modern physics, physiology and sociology; the increasing use of electricity, the invention of radio and the cinema; the beginnings of mass production; the publishing of mass-circulated newspapers; the new structural possibilities offered by the availability of steel and aluminum; the rapid development of the chemical industries and the production of synthetic materials; the appearance of the motor car and the aeroplane. ${ }^{15}$

Keiller leaves out the question that ends Berger's list in the original - "what did all this mean?" - but he seems to be suggesting that, given this state of affairs, it is hardly any wonder that Lefebvre claimed "a certain space was shattered". This is especially the case if we add to Berger's list of transformations the massive social upheaval that resulted from large-scale emigration, the end of empire, and the Great War. ${ }^{16}$

13. Ibid., p. 191. Significantly, Keiller extracts this quote not from the opening chapter of The Production of Space, where it first appeared, but from the geographer David Harvey's afterword to the 1991 English edition, and he notes that Harvey had already quoted this exact passage once before in his edition of The Condition of Postmodernity: An Enquiry into the Origins of Cultural Change, Cambridge (Mass.), Blackwell Publishing, 1990.

14. Keiller, 2004, p. 191-192.

15. Ibid., p. 191.

16. John Berger, The Moment of Cubism and Other Essays, London and New York, Weidenfeld and Nicolson and Pantheon Books, 1969, p. 5. 
Not surprisingly, given the magnitude of the forces at play, Keiller notes that these late-20 $0^{\text {th }}$ century critics weren't the first to depict the period "around 1910" in this manner, and that, in fact, a number of intellectuals who had lived through the "moment of cubism" and its aftermath came to very similar conclusions decades earlier. Keiller singles out Laszlo Moholy-Nagy and Walter Benjamin in particular, and he proceeds by quoting a famous and oft-cited passage from "The Work of Art in the Age of Mechanical Reproduction": ${ }^{17}$

Our taverns and our metropolitan streets, our offices and furnished rooms, our railroad stations and our factories appeared to have us locked up hopelessly. Then came the film and burst this prison-world asunder by the dynamite of the tenth of a second, so that now, in the midst of its far-flung ruins and debris, we calmly and adventurously go traveling. ${ }^{18}$

Now, Keiller introduces this material in order to establish a foundation for his own idiosyncratic take on a series of pre-1910 electric tram films produced by the Mitchell \& Kenyon company in a number of British cities, such as Nottingham, Halifax, Sheffield, and Manchester, one which compares images of these cities as they appeared in Edwardian times with images of those same cities today toward an analysis of their spatial structures and their transformation over time. ${ }^{19}$ But his comments also address the intersection between two tendencies that have been central to film studies for some time now: its "spatial turn" and its ongoing fascination with "modernity." Quite explicitly, in fact, for Keiller discusses these cultural shock waves in terms of "evolving concepts of space," and soon afterwards ties them directly to Moholy-Nagy's Dynamic of the Metropolis (1921-1922), his sketch for a film, two later Moholy-Nagy films, Berliner Stilleben (1926) and Marseille, vieux port (1929), and Dziga Vertov's Chelovek s kinoapparatom (Man with a Movie Camera, 1929).

What Keiller only hints at in his "Tram Rides and Virtual Landscapes" essay, but which is nevertheless suggested by his references to Moholy-Nagy's Dynamic of the Metropolis and Vertov's Man with a Movie Camera, is that sometime in the early $20^{\text {th }}$ century there emerged a film aesthetic that was a product of and a response to this "shattered space," and that the city films and "city symphonies" of the 1920 and 1930 s were prime examples of this development. This line of thinking becomes clearer if we look at the body of writing Keiller has produced over

17. This passage is taken from Harvey, 1990, once again, instead of from one of Benjamin's texts.

18. Keiller, 2004, p. 192.

19. Ibid., p. 193-199. 
the last decade, as well as the interviews he's given. Thus, one recurring figure is that of Lev Kuleshov, whose early experiments with film and their subsequent theorization created the foundation for one of the most influential filmmaking schools of the early $20^{\text {th }}$ century. Characteristically, however, it is not the famous "Kuleshov effect" experiments involving the actor Mozhukhin that have been the source of Keiller's fascination. Instead, it is the experiments with "artificial landscapes" and "creative geography" that interest him, the engagements with cinematic space that led Kuleshov to the conclusion that, through montage, one "was able to alter the very essence of the material" one captured with the camera, making it possible "to create a new earthly terrain that did not exist anywhere". ${ }^{20}$ Famously, it was Sergei Eisenstein who ridiculed Kuleshov (his former mentor) in his essay "The Cinematographic Principle and the Ideogram," making fun of the "old, old school of film-making" represented by Kuleshov, and especially of the "pernicious" notion that shots were "like bricks" and montage like brickwork. ${ }^{21}$ What Keiller seems to have understood, unlike Eisenstein, is that Kuleshov was equally if not more interested in the effects of montage on bricks, that Kuleshov's work provides an early instance of what Keiller calls "architectural cinematography," and that this may be Kuleshov's most lasting legacy.

Keiller also returns to the figure of Louis Aragon on more than one occasion in his writings, and while Aragon's Surrealist writings, and especially Le paysan de Paris (Paris Peasant, 1926), are of great significance for this self-proclaimed "surrealist groupie," of comparable significance is Aragon's very first publication, his 1918 proto-Surrealist film theory essay "On Décor". ${ }^{22}$ Here, Aragon writes of "two properties" that help make cinematic mise en scène, or cinematic décor, representative of "modern beauty": its ability "[to] endow with a poetic value that which does not yet possess it," and its ability "to willfully restrict the field of vision so as to intensify expression". ${ }^{23}$ Keiller comments that in the first of these cinematic properties we see the expression of a sensibility that anticipates Aragon's cultivation of a "surrealist subjectivity," ${ }^{4}$ one capable of transfiguring "whole

20. Keiller, 2002, p. $3^{8}$.

21. Sergei Eisenstein, "The Cinematographic Principle and the Ideogram," in Film Form: Essays in Film Theory, ed. and trans. Jay Leyda, New York, Harcourt, Brace and Company, 1949, p. 36.

22. Tony Rayns, "Simply Capital," Time Out, 1 June 1994, p. 61.

23. Keiller, 2002, p. 37.

24. Ibid., p. $3^{8}$. 
districts of the city," ${ }^{25}$ while the second "effectively describes film space". ${ }^{26} \mathrm{He}$ writes:

Films are made of images with a field of view which is very narrow compared with experience of actual, three-dimensional space. The space of a film is assembled from fragments, their relationship inferred from cues in action, sound or narrative. Most film space is off screen - it's either remembered from preceding images, or heard, or merely the imaginary extension of the space on screen. Because it is reconstructed in this way, film space is always a fiction, even when the film is a documentary. ${ }^{27}$

Here again, in the period immediately following Lefebvre's "around 1910," when the reverberations from film's "dynamite of the tenth of a second" (Benjamin) were first felt, Keiller locates a growing awareness among filmmakers and film theorists of film's ability to engage with space (and especially the period's emerging urban spaces), a growing awareness of film as a medium with the potential to engage in "spatial critique." Indeed, Keiller has returned to the basic argument presented in "Tram Rides" twice in recent years: ${ }^{28}$ once under the somewhat vague title "Urban Space and Early Film," and, subsequently, in the text "Film as Spatial Critique." ${ }^{29}$ In any case, it is the tradition of the city film (both pre-World War II and post-) to which Keiller's films most clearly belong, and his writings indicate that, perhaps, film's potential to examine and engage with the built environment was only rarely (if ever) fully realized.

While Keiller's essays are often highly original works of cultural history, his interest in the intersection between early $20^{\text {th }}$ century film, film theory, and early $2 \mathrm{O}^{\text {th }}$ century urban modernity is hardly unique. As mentioned above, for at least two decades now, the field of film studies has displayed a profound fascination with both space (urban, social, "abstract," and so on) and modernity. One might cite Anne Friedberg, Anthony Vidler, Kristin Ross, and Edward Dimendberg as being among those scholars who have explored this intellectual territory. What distinguishes Keiller's work from that of these other film scholars is that he has

25. Keiller, 2003 , p. 78.

26. Keiller, 2002, p. $3^{8 .}$

27. Ibid.

28. Surely this must indicate the significance of this argument to Keiller's larger body of work.

29. Patrick Keiller, "Urban Space and Early Film," in Andrew Webber and Emma Wilson (eds.), Cities in Transition: The Moving Image and the Modern Metropolis, London and New York, Wallflower Press, 2008, p. 29-39, and Patrick Keiller, "Film as Spatial Critique," in Jane Rendell, Jonathan Hill, Murray Fraser and Mark Dorrian (eds.), Critical Architecture, London and New York, Routledge, 2007, p. 115-123. 
pursued these ideas in film, using the medium to explore this very same terrain. Consequently, the centrality of the work of Henri Lefebvre and Walter Benjamin to Keiller's thinking is evident not only in his writings, but also directly in his filmmaking. In fact, their respective methodologies are built right into Keiller's two most famous films, to such an extent that we can say that London is an explicitly Benjaminian film that nevertheless displays an approach to studying urban space that is implicitly Lefebvrian, while Robinson is an explicitly Lefebvrian film that maintains an implicitly Benjaminian approach to history and its creation.

Thus, on the one hand, Robinson, Keiller's chief protagonist in London, is a scholar who is openly familiar with the work of Benjamin, and who is engaged in a research project on "the problem of London" that on some level is his very own Passagen-Werk, right down to its pursuit of arcades-like settings for his writing. More importantly, though, is the way Keiller draws from Benjamin himself, so that Benjamin's influence is felt both within the narrative and exterior to it (i.e., on a documentary level). So while Benjamin drew great inspiration from the aesthetics of montage - cinematic montage in particular - and explicitly sought a "cinematic" form for such works as One-Way Street ${ }^{30}$ and The Arcades Project, ${ }^{31}$ Keiller incorporates a "literary montage" aesthetic into his film, including a considerable number of quotations, in a manner that directly calls to mind aspects of The Arcades Project. As a result, London creates a very strong sense of the city-as-palimpsest, a city that is both "geological" and composed of many historical layers, as well as the textual city, a city composed of layers of text, qualities that are once again reminiscent of The Arcades Project. While the measured pace of Keiller's film in no way resembles Benjamin's famous "dynamite of the tenth of a second," the film's use of visual montage is consistent with Benjamin's interest in shock effects (if oftentimes subtle ones); its seriality, its attraction to the city's "detritus," and its compositional eye demonstrate an interest in the work of Eugène Atget shared with Benjamin, his friend and colleague Siegfried Kracauer, and the Surrealists. The film is also very consciously a "flâneur film," one that combines elements that are Baudelairean, Rimbaldian, Surrealist, and Situationist, as well as Benjaminian, one that uses flânerie to stitch together urban

30. Walter Benjamin, One-way Street and Other Writings, trans. Edmund F. N. Jephcott and Kingsley Shorter, London, Verso, 1979.

31. Walter Benjamin, The Arcades Project, trans. Howard Eiland and Kevin McLaughlin, Cambridge (Mass.), The Belknap Press of Harvard University Press, 2002. 
space, literary montage, and history, to make sense of a city that has become, "an absence, a necropolis of fretful ghosts, a labyrinth of quotations." 32

On the other hand, Keiller's protagonists (Robinson and the Narrator) appear to be just as well versed in the writings of Henri Lefebvre, and especially The Production of Space, ${ }^{33}$ as Keiller himself is, because the second film in the diptych, Robinson in Space, is explicitly Lefebvrian in nature. The reasons for this are twofold: the film's attempts to come to terms with "the problem of England" inevitably lead to the post-industrial landscape outside the city centers, to the freeways, shopping centers, and industrial parks synonymous with the shift in spatiality that is the focus of so much of Lefebvre's work; they also lead to an analysis of how such spaces are produced and reproduced. The film's narrative begins on a pessimistic note, the sole passage from Lefebvre that appears in the film only augments this pessimism, and it's safe to say that the overall tone of the film is one of melancholy, but the film itself tempers any sense of defeatism with a display of how postmodernity's "layered spatialities" can be deciphered, its "abstract spaces" appropriated and transformed with the camera. "To change life..., we must first change space," Lefebvre argues in The Production of Space, ${ }^{34}$ and while the context is one of social revolution, Keiller provides an example of how the camera might point towards the "preconditions of another life" and perhaps even begin to envision it. ${ }^{35}$

What follows is an examination of Keiller's attempt to use film as a medium of spatial critique, one that, in the interest of brevity, limits itself to just one film and just a few concrete examples. Keiller has worked on other film projects over the course of the last decade, and he is currently involved in a multi-year research project with Doreen Massey and Patrick Wright called "The Future of Landscape and the Moving Image" that will include a feature film contribution, but, for the moment, Keiller's two Robinson films remain the strongest examples of his engagement with film, theory, and the built environment. In part, this is because their non-archival nature allows us to see how Keiller constructs his images beyond mere montage, but it is also because they are the most readily available of Keiller's films. Given its pertinence to the theme of this issue of Intermédialités, it is to Robinson in Space that I now turn.

32. Iain Sinclair, London Orbital: A Walk Around the M25, London, Penguin Books, 2002 , p. 13.

33. Henri Lefebvre, The Production of Space [1974], trans. Donald Nicholson-Smith, Oxford, Blackwell, 1991.

34. Ibid., p. 189-19o.

35. Keiller, 2002, p. 37. 


\section{BUILDING BRIDGES, NEW SPACE}

Reality as it evolves sweeps me with it. I'm struck by everything and though not everything strikes me in the same way, I'm always struck by the same basic contradiction. Although I can always see how beautiful anything could be if I could only change it, in practically every case there is nothing I can really do. Everything is changed into something else in my imagination. Then the dead weight of things changes it into what it was in the first place. A bridge between imagination and reality must be built.

With this passage from Raoul Vaneigem's The Revolution of Everyday Life, spoken by the Narrator (once again performed with great panache by Paul Scofield, as it was in London) and set against a tracking shot taken from a train heading west away from London's Paddington Station, Patrick Keiller launches Robinson in Space, his sequel to London. Once again we, the audience, are presented with the exploits of Robinson and the Narrator, and neither is ever depicted onscreen. Once again, the film displays an interest in what Keiller (following Vaneigem and the Situationists, not to mention the Surrealists before them) calls "revolutionary subjectivity" 36 or "more-or-less radical subjectivity." 37 Keiller associates these phrases with "the subjective transformation of already existing space," through the use of the motion picture camera ${ }^{38}$ and the "phenomenon of photogénie," through its ability to transform space and render it strange. "Films don't represent experience of architecture," Keiller has said, "they reconstruct it". ${ }^{40}$ But here this concept is quite explicitly tied to the notion

36. Patrick Wright, "A Conversation with Patrick Keiller," in Keiller, Robinson in Space, London, Reaktion Books, 1999, p. 230.

37. Patrick Keiller, "Port Statistics," in Iain Borden, Joe Kerr, Jane Rendell and Alicia Pivaro (eds.), The Unknown City: Contesting Architecture and Social Space, London and Cambridge (Mass.), MIT Press, 2001, p. 442-458 (here, p. 444). The passage above comes from a section in chapter 23 of Vaneigem's book entitled "Radical Subjectivity."

38. Joe Kerr, “To Change Life, However, We Must First Change Space’: Patrick Keiller Interviewed by Joe Kerr," Architectural Design 70.1, January 2000, p. 82-85 (here, p. 82).

39. Keiller, 2002, p. 37. James Donald has written about Keiller's stubborn, eccentric commitment to photogénie, which he describes as having provided an alternative to cinematic montage in the film theory of the avant-garde of the 1920s. According to him, Keiller interprets the term as having to do with "the power of the camera to reveal the strangeness of familiar objects," an argument that points towards Keiller's deep fascination with the work of Viktor Shklovsky and the concept of ostranenie. James Donald, Imagining the Modern City, Minneapolis, University of Minnesota Press, 1999, p. 185.

40. Joe Kerr, 2000 , p. 83 . 
of representational space that Henri Lefebvre opposes to the abstract space and its "reproducibility, repetition, and reproduction of social relationships" in The Production of Space. ${ }^{41}$ As Edward Dimendberg explains,

Representational spaces... need obey no rules of consistence or cohesiveness. Redolent with imaginary and symbolic elements, they have their source in history - in the history of a people as well as in the history of each individual belonging to that people. ${ }^{42}$

In fact, the Narrator announces this minutes later. Having lost his job as a university lecturer and suffered from a bout of depression in the years since the publication of his study of London, the film begins with Robinson living in Reading where he teaches English in a language school. Despite the squalor of his day-to-day existence (poor accommodations, a "poorly paid and insecure" job, a bad diet, and no friends), the Narrator finds Robinson strangely upbeat, entranced by Reading's literary associations (Rimbaud, Austen, Wilde, and even a vague connection to Conan Doyle's Sherlock Holmes) and seemingly oblivious of the town's overwhelming provincialism. The Narrator is skeptical of Robinson's newfound enthusiasm and his Rimbaldian "commitment to the derangement of the senses" in a locale as inhospitable as Reading. "I did not think that Robinson's move to Reading was a good one," he announces.

Despite his vision, "that other people could become fellows and neighbors," the fact is that, as Lefebvre says, "The space which contains the realized preconditions of another life is the same one as prohibits what those preconditions make possible."

The passage comes from a section of The Production of Space in which Lefebvre discusses modernity and "mirage effects" - the notion that "the illusion of a new life is everywhere reinforced" - to come to the conclusion, in a passage that speaks directly to Robinson's state of mind (as well as Vaneigem's), that:

[the] seeming limpidity of... space is... a delusion: it appears to make elucidation unnecessary, but in reality it urgently requires elucidation. A total revolution - material, economic, social political, psychic, cultural, erotic, etc. - seems to be in the offing, as though already immanent to the present. To change life, however, we must first change space. ${ }^{43}$

41. Lefebvre, 1991, p. 41.

42. Edward Dimendberg, Film Noir and the Spaces of Modernity, Cambridge (Mass.), Harvard University Press, 2004, p. 106.

43. Lefebvre, 1991, p. 189-19o. 
With Robinson in Space, Patrick Keiller presents the audience once again with what one might call a cinema of surfaces - in fact, the film's opening section on Reading ${ }^{44}$ also includes a clever détournement of a famous passage from Wilde's The Picture of Dorian Gray which underlines the film's peculiar cinematographic approach: "It is only shallow people who do not judge by appearances. The true mystery of the world is the visible, not the invisible." And once again, while fully admitting that his method might not be entirely revolutionary, Keiller's film attempts to "change space" with the use of a motion picture camera, evidently as some kind of first step towards something more radical. This time, however, the film is terser, somewhat less meandering, and, following Lefebvre, it makes a more concerted effort to elucidate space. As Keiller himself puts it:

Whereas London set out to transform appearances through a more-or-less radical subjectivity, Robinson in Space addresses the production of actual space: the manufacture of artifacts and the development of sites, the physical production of the visible. $^{45}$

The Narrator needn't have worried too much about Robinson's state of mind. As in the case of London, it turns out that the Narrator has been summoned by Robinson to act as witness to a series of investigations. Whereas Robinson's study of the "problem of London" was self-motivated, though, this time things are different. The Narrator explains:

He told me that some weeks before, he had received a letter from a representative of a well-known international advertising agency inviting him to a meeting at the hotel. These people had heard of his study of London and wished to commission him to undertake a peripatetic study of the problem of England. He had accepted this offer with alacrity and insisted that I join him as researcher.

The pair makes a series of initial investigations in the Reading area, seemingly at random - including visits to an HMV store, where Adam Ant is making an appearance, a neo-con stronghold ("admired by Gingrich Republicans in the United States") known as the Winnersh Triangle, and West Green, the former home of General Henry "Hangman" Hawley - and the Narrator

44. Typical of Keiller's bizarre sense of humor, a footnote to Robinson in Space (the heavily annotated book version) reads:

Robinson's decision to move to Reading was reinforced by his hasty misreading of Michel de Certeau's Practice of Everyday Life: "Reading frees itself from the soil that determines it" and “... reading is... a place constituted by a system of signs.” Keiller, 1999, p. 2.

45. Keiller, 2001, p. 444. 
remarks upon these apparently benign locations with a well-known but nevertheless choice quote from The Adventures of Sherlock Holmes, one that proves prescient:

"It is my belief, Watson," said Holmes, "founded upon my experience, that the lowest and vilest alleys in London do not present a more dreadful record of sin than does the smiling and beautiful countryside."

Not long afterwards, on their way back to Reading, Robinson informs the Narrator that he has received instructions from their mysterious employer and that they are to begin the first of seven journeys back and forth across the English countryside the very next day. This odd method had been derived from Robinson's reading of Daniel Defoe's Tour through the Whole Island of Great 118 Britain, itself an idiosyncratic travelogue. ${ }^{46}$ Defoe is fascinated by the juxtapositions between "novelty" and "antiquity" that he sees all around him as he travels the nation, and in the opening pages of his Tour he describes the sea change underway:

The Fate of things gives a new Face to Things, produces Changes in low Life, and innumerable incidents; plants and supplants Families, raises and sinks Towns, removes Manufactures, and Trade; Great Towns decay, and small Towns rise; new Towns, new Palaces, new Seats are Built every Day; great Rivers and good Harbours dry up and grow useless; again, new Ports are open'd, Brooks are made Rivers, small Rivers, navigable Ports and Harbours are made where none were before, and the like. ${ }^{47}$

Robinson appears to be engaged in a very similar pursuit, except that, unlike Defoe, who was employed as a spy for the government of Queen Anne, Robinson seems much less concerned with protecting England's "Face," and much more willing to "write a History of her Nudities, and expose... her wicked part to

46. It bears noting that even though Defoe plays a major role in both London and Robinson in Space, and London's Third Expedition begins with Robinson haunted by Defoe's novel of "shipwreck... and Protestant isolation," apparently "Robinson" is not a reference to "Robinson Crusoe" - at least, not primarily. Nor is the name a reference to Louis-Ferdinand Céline's Journey to the End of the Night (1934) or Chris Petit's Robinson (1993) - again, not primarily. According to Keiller, the name came from Kafka’s Amerika, and he was particularly attracted by the name's generic qualities: "It occurred to me that apart from the obvious borrowing from all the other Robinsons, Robinson was the kind of English name that you can encounter in a text book. So much so that it is quite clearly the name of an imaginary person." Claire Barwell, "Interview with Patrick Keiller," in Halberstadt, 1997, p. 160-161.

47. Daniel Defoe, A Tour Thro' the Whole Island of Great Britain, [1724-1726], London, Frank Cass and Co., 1968, p. 1-2. 
Posterity." "48 "The narrative of Britain since Defoe's time is the result of a particularly English kind of capitalism," the Narrator tells us, in a configuration that we might call the project's hypothesis. So with a copy of Port Statistics, "a publication of the Government's Statistical Service," and a copy of Capitalism, Culture and Decline in Britain, 1750-199o, W. D. Rubinstein's groundbreaking debunking of the critique of "gentlemanly capitalism,"49 Robinson and the Narrator set off on the first of their journeys, "[following] the Thames downstream to the sea" but carefully sidestepping London for fear of "reprisals" due to Robinson's earlier study.

While Keiller's project shares a lot in common with that of Robinson and the Narrator, and one might also characterize it as amounting to a study of the "problem of England," as was the case with London, one can point to a number of discrepancies between the two projects, both diegetic and extradiegetic. After all, why else adopt such an unorthodox multi-layered form if you're not going make use of the multiple layers? So, for instance, as Keiller suggests in a footnote to Robinson in Space, Robinson's commissioned study is a satirical reference to what would soon blow up into the "Elwes Affair" in 1997: "Nations for Sale, a study of Britain's overseas image, was produced in 1994 by Anneke Elwes for the

\section{Defoe, 1968, p. 2.}

49. Among the earliest examples of this critique was Martin J. Wiener, English Culture and the Decline of the Industrial Spirit, 1850-1980, Cambridge (Mass.), Cambridge University Press, 1981.

In his essay "Port Statistics," Keiller writes that this critique "sees the United Kingdom's economic weakness as a result of the City of London's long-term (English) neglect of the (United Kingdom's) industrial economy, particularly its manufacturing base" Keiller, 2001, p. 443.

Rubinstein summarizes his approach thusly:

Our argument is that the most fundamental assumption made by the advocates of the "culture critique" [what Keiller refers to as the critique of "gentlemanly capitalism"] is wrong, namely that Britain's was centrally an industrial economy whose industrial and manufacturing lead vanished through qualitative decline after 1870 . The view which will be advanced here is that Britain's was never fundamentally an industrial and manufacturing economy; rather, it was always, even at the height of the industrial revolution, essentially a commercial, financial, and service-based economy whose comparative advantage always lay with commerce and finance. Britain's apparent industrial decline was simply a working out of this process... What is so often seen as Britain's industrial decline or collapse can be seen, with greater accuracy, as a transfer of resources and entrepreneurial energies into other forms of business life.

W. D. Rubinstein, Capitalism, Culture, and Decline in Britain, 1750-1990, London, Routledge, 1993, p. 24. 
international advertising network DDB Needham." He adds, with a few wellchosen phrases (and characteristic irony), "that Elwes found Britain 'a dated concept,' difficult 'to reconcile with reality,' with a 'brand personality' entrenched in the past". ${ }^{50}$ More generally, though, while Keiller is clearly sympathetic to his characters, and there's even a certain degree of autobiography that's thrown into his narrative, ${ }^{51}$ he uses them to explore his own discovery that his "perception of the UK's economy was completely out of date," locked in a "1980s perception." This particular epiphany is very much central to the film's narrative. His protagonists are not making a film, though, and, unlike London, there's no mention that they're even carrying still cameras to shoot "postcards" - the images we're presented with are Keiller's, and frequently they're used in counterpoint with his narrative. Put another way, Keiller's protagonists might cite Lefebvre, but it's Keiller himself who attempts to translate Lefebvre's thoughts into an aesthetic that's cinematic, photographic, and essayistic, and while Robinson's contract is terminated abruptly, his study incomplete and its future uncertain, not only did Keiller's filmic study of "the problem of England" see the light of day, but Keiller produced an accompanying book and a considerable number of probing extra-filmic texts in the years that followed the film's release. ${ }^{52}$ All of these

50. Keiller, 1999, p. 6. What Keiller didn't know at the time was that Nations for Sale was about to blow up into the "Elwes Affair," as Elwes' former employer, Chris Powell, suddenly became the Chief of Staff at 10 Downing Street following "New" Labour's landslide victory in 1997:

Suddenly, "Nations for Sale" was being read by powerful people committed to shaking things up, to making an old nation young again. Studies were undertaken. Consultants were hired. The prestigious Panel 2000 of business and government leaders was assigned to the task. Time and Newsweek splashed London across their pages as the epicentre of cool. Hipster think-tank Demos released a paper called "Britain ${ }^{\text {TM }}$ Renewing Our Identity"... The rebranding of the place called Britain had begun. (See Timothy Taylor, "This Brand is Your Brand," EnRoute, May 2005, www.enroutemag.com/e/mayo5/ essay.html - last access June 4, 2010)

Next stop: Cool Britannia.

One might add, the Tories are still in power as Robinson in Space unfolds, and there are signs that this situation is about to change, but part of what makes the film so chilling is its Lefebvrian pessimism with regards to political "mirages." Fittingly, the nation is undergoing an unprecedented heat wave throughout the film.

51. For instance, both Keiller and Robinson hail from Blackpool.

52. These include his essay "Port Statistics," which can be understood as a détournement of the GSS's document much in the same way as Keiller's London amounts to a détournement of the actual, official city. 
attempted to reinforce and expand upon the film's critique in such a way as to transform the film into something more than just an example of "provocative, determinedly left-field filmmaking." ${ }^{3}$ Thus, Robinson in Space is both a narrative of the attempt "to undertake a peripatetic study of the problem of England" and the mixed-media documentary that results of such a study.

Not surprisingly, given the type and scale of the two studies - one metropolitan, the other national - the movements of Keiller's two peripatetic studies are rather different. While the portrait of London that one gets in London is an unconventional one, largely avoiding the city's major sights and consisting of a series of obscure pilgrimages which travel the very fringes of the metropolitan region with some frequency, ultimately the movements of Robinson and the Narrator remain largely centripetal, in spite of the empty focal point that Dimendberg (following Lefebvre) has described as being a hallmark of the "centrifugal space" so characteristic of both late modernity and postmodernity. Their patterns of movement in Robinson in Space, on the other hand, reflect little of this nostalgia for a bygone form of urbanism. Though the film begins in the centre of London, it only revisits the metropolis once, and then only in passing, the camera jumping from Heathrow Airport to Greenwich, "near the site subsequently chosen for the Millennium exhibition," while Robinson and the Narrator travel through the maze of tunnels that make up the London Underground. Otherwise, the film visits a number of small, medium, and large cities - including Birmingham, Liverpool, and Manchester - but none exerts any more pull than any of the rest, ${ }^{4}$ and, if anything, the film's focus is diffuse. Instead of letting London's vaguely apocalyptic conclusion dangle, Robinson in Space follows up on it, seeking to make sense of the void. Thus, as Keiller explains:

[Towards] the end of London there is a line - "The true identity of London is in its absence" - to which the viewer might reply: "Absence of what?" London began and grew as a port city; its port activity is now mostly absent, but it continues elsewhere. Robinson in Space was an attempt to locate some of the economic activity that no longer takes place in the cities. ${ }^{55}$

Like London, Robinson in Space is very much a film about urbanism, but it's about urbanism according to another economic logic, one that's predominantly

53. Geoff Andrew, "Robinson in Space," Time Out, 8 January 1997, p. 69.

54. Not much more, in any case. Manchester gets a bit more attention than any of the rest because "[from] the film's point of view" it was "the most interesting city," as we shall see. Patrick Wright, “A Conversation with Patrick Keiller," in Keiller, 1999, p. 223-235.

55. Ibid., p. 223-224. 
centrifugal. There's the sense here that what Iain Sinclair (echoing Defoe) has called "a new kind of England" 56 - a transitory, transient England - requires a new approach. But whereas Sinclair's approach in both the book and film versions of London Orbital is to circumnavigate the $\mathrm{M}_{25}$, London's gigantic postmodern péripherique, on foot because central London is "overwritten," ${ }^{57}$ Keiller's method is somewhat more probing, motivated by the belief that if one is to understand the reign of abstract space, one must visit those sites where what he calls "new space" is being produced and reproduced and contend with its "immateriality, invisibility, and speed," ${ }^{15}$ while continuing to show an understanding and appreciation of English culture that recalls Raymond Williams' landmark The Country and the City..$^{59}$

Thus, explaining the film's peculiar approach to urbanism, Keiller told Patrick Wright:

The subject was new space, and generally new space is found outside or on the edge of cities. The pictures are more or less what we found. In fact, we didn't find it for a long time; we spent quite a lot of time early on in the project wondering where the new space was - it wasn't visible enough. ${ }^{60}$

Dimendberg describes "the most striking feature of centrifugal space" as being its "frequently nonarchitectural character" and this is exactly the paradox that we're confronted within Robinson in Space: a sweeping depiction of the built environment of contemporary England that's highly "nonarchitectural," even when representing "the architecture of the future."61 As materialists who value "an authenticity of appearance" and who rue "the passing of the visible,"

56. Iain Sinclair and Chris Petit's film London Orbital, 2002.

57. This quote comes from an interview with Iain Sinclair and Chris Petit that appears as a bonus feature on the DVD release of Sinclair \& Petit's film, London Orbital.

58. Edward Dimendberg, Film Noir and the Spaces of Modernity, Cambridge (Mass.), Harvard University Press, 2004, p. 177.

59. Towards the end of The Country and the City, Williams writes a passage that speaks directly to Keiller's approach with this film:

The country and the city are changing historical realities, both in themselves and in their interrelations. Moreover, in our own world, they represent only two kinds of settlement. Our real social experience is not only of the country and the city, in their most singular forms, but of many kinds of intermediate and new kinds of social and physical organization.

Raymond Williams, The Country and the City, London, Chatto and Windus, 1973, p. 289 .

6o. Wright, 1999, p. 228.

61. Dimendberg, 2004, p. 178. 
Robinson and the Narrator are often bewildered by the new spaces that are characteristic of Britain's late $20^{\text {th }}$ century neo-liberal economy, and by the immateriality and insubstantiality that defines them. The very blankness of these spaces requires an aesthetic that is consistent with London, but which is able to navigate a very different environment. As Keiller explains in his essay "The Dilapidated Dwelling,"

Most of the new space is occupied by large corporations of one sort or another, a few of them international in scope, and it is not urban in the conventional sense. It includes retails sheds, supermarkets, fast food restaurants, a Travel Inn, a business park, distribution warehouses, tyre, exhaust and windscreen service centres. Most of these places have large car parks and security cameras. There is a lot of new space under construction, it goes up fast, and more is proposed. Buildings in new space do not have to last very long. In some of the older new space the original buildings have already been replaced by new ones. ${ }^{62}$

In order to capture the shock experienced by his protagonists while, at the same time, elucidating the spaces depicted - situating them, contextualizing them, establishing linkages between them, making sense of them - Keiller utilizes subtle montage-based "shock effects" in conjunction with what we might call (following Dimendberg) "layered spatialities."

Thus, one of the things that makes Keiller's treatment of "new space" - of the "so-called market-driven space" ${ }^{164}$ of business parks, distribution estates, and leisure parks - so fascinating (against all odds), is the way Keiller embeds the banal landscaping so typical of late $20^{\text {th }}$ century corporate architecture in a centuries-old history of English landscape, a tradition "widely acknowledged to be the most influential force in the last two centuries of landscape design" and, as Keiller would have it, a signal moment in the history of capitalism's production of space. ${ }^{65}$ This point is made all too clear early on in the film in a sequence which connects West Green, "the former home of Alistair, Lord McAlpine, treasurer of the Conservative Party between 1975 and 1990" (i.e., the Thatcher era), with the "Winnersh Triangle business and distribution park" mentioned earlier, by way of Sherlock Holmes' assessment of "the smiling and beautiful countryside."

62. Patrick Keiller, "The Dilapidated Dwelling," in Sarah Wigglesworth and Jeremy Till (eds.), The Everyday and Architecture, London, Architectural Design, 1998, p. 22-27 (here, p. 22).

63. Dimendberg, 2004, p. 8.

64. Wright, 1999, p. 227.

65. Gina Crandell, Nature Pictorialized: "The View" in Landscape History, Baltimore and London, Johns Hopkins University Press, 1993, p. 9. 
The images that Keiller chooses to illustrate Winnersh Triangle, which sits in the constituency of John Redwood, "admired by Gingrich Republicans in the United States as the leader of the 'revolutionary wing of Great Britain's Conservative Party," include a shot of the landscaped grounds of US Robotics' UK headquarters and a shot of enormous American-style mansions sitting clumped together in the heavily landscaped confines of a gated community. The combination of landscaped lawn, shrubs, and trees that define these American-style "new spaces" are imitative of the $18^{\text {th }}$ century English garden style established by estates like West Green, ${ }^{66}$ and, thus, what Keiller's sequence of shots emphasizes is the way the history of English landscaping has come full circle.

Generally, though, the connections that tie Keiller's representations of "new space" with landscape aren't quite so clear. More often than not these representations are like that of Merry Hill, whose "affirmative culture" Keiller brackets between Blakenhurst Prison and an exclamation mark-bearing road sign calling attention to an accident. The thicket of signs in the sequence's first shot announces that Merry Hill is something of a commercial hub, but, as the six-shot scene proceeds, the Narrator informs us as to the scope:

Merry Hill, near Dudley, is the largest shopping centre in Europe. More than 4.5 million people are within a sixty-five-minute drive.

It is connected to the nearby Waterfront development by a monorail, though this was not operating on the day of our visit...

Merry Hill attracts 25 million shopping visits a year, and its effects are felt in towns 200 miles away.

The significance (and the poignancy) of Merry Hill and the Waterfront comes from the fact that, as the Narrator indicates, these developments "were built on the site of the former Round Oak steelworks," a factory which dated back to the $19^{\text {th }}$ century, when "the majority of iron-making in the world was carried out within thirty-two kilometers" of this very location. Most of the Merry Hill shots convey a sense of the chaos (both vehicular and architectural) that defines its sprawl, but continuing with the "arcades project" he began in his first Robinson film, Keiller also provides the audience with a rare interior shot - sunlight streaming through the skylights in one of the mall's many arcades - to give a sense of Merry Hill's inner workings. And here, in a reprise of Robinson's

66. Not to mention Cliveden, Charborough Park, and Stowe, all of which are featured later in the film. 
"The failure of the English Revolution is all around us" thesis from London, Keiller cleverly uses the complex's interior itself to deliver his verdict on Merry Hill - a sign in the foreground, the sign that's most clearly legible, reads "Cromwell's Mad House."

What we see, then, in the essays and interviews of Patrick Keiller is an understanding of how early $20^{\text {th }}$ century modernity not only exploded the organization of space as it had existed, but brought about an awareness (tentative, perhaps) of film's potential for exploring these new spatial arrangements and reconfiguring them, and even critiquing them. While in his films, we see how Keiller has aligned himself with this tradition of filmmaking and sought to capitalize upon this potential for an "architectural cinematography." "Since the 1970s," Keiller writes,

architects have explored cinema as a source of spatial concepts applicable to architecture, ... [but] it seems to me - as an architect diverted into making films - that film has a more general significance for architecture as a means of developing a critique, temporal and otherwise, of actual architectural and urban space.

Furthermore, film holds the "capacity to imaginatively transform alreadyexisting space." ${ }^{\prime 67}$ Keiller's 1997 Robinson in Space provides a vivid example of this film aesthetic at work, a vivid example of how film might engage in the elucidation of space, while simultaneously transforming this space, building bridges between imagination and reality. 